\title{
EFIKASI HERBISIDA GLIFOSAT TERHADAP GULMA UMUM PADA PERKEBUNAN KARET (Hevea brasiliensis [Muell.] Arg) YANG SUDAH MENGHASILKAN
}

\author{
Evi Oktavia, Dad R. J. Sembodo \& Rusdi Evizal \\ Jurusan Agroteknologi, Fakultas Pertanian Universitas Lampung \\ Jl. Prof. Dr. Soemantri Brodjonegoro no. 1 Bandar Lampung 35145
}

\begin{abstract}
ABSTRAK
Penelitian ini bertujuan untuk mengetahui efektifitas herbisida Isoprofil Amina (IPA) Glifosat, untuk mempelajari perubahan komposisi jenis gulma setelah aplikasi IPA glifosat, dan untuk mengetahui pengaruh keracunan herbisida IPA glifosat pada tanaman karet menghasilkan. Penelitian ini dilaksanakan di lahan perkebunan PTPN VII Unit Usaha Way Galih dan Laboratorium Ilmu Gulma Fakultas Pertanian Universitas Lampung. Penelitian ini disusun dengan 6 perlakuan dengan 4 ulangan. Susunan perlakuan sebagai berikut yaitu isopropil amina glifosat $720 \mathrm{~g} \mathrm{ha}^{-1}$, isopropil amina glifosat $960 \mathrm{~g} / \mathrm{ha}$, isopropil amina glifosat $1200 \mathrm{~g} \mathrm{ha}^{-1}$, isopropil amina glifosat $1440 \mathrm{~g} \mathrm{ha}^{-1}$, pengendalian mekanis dan kontrol. Homogenitas ragam diuji dengan uji Bartlet, aditivitas diuji dengan uji Tukey, dan perbedaan nilai tengah diuji dengan Uji Beda Nyata Terkecil (BNT) pada taraf $5 \%$. Hasil penelitian menunjukkan bahwa herbisida glifosat pada dosis $720 \mathrm{~g} \mathrm{ha}^{-1}-1440 \mathrm{~g} \mathrm{ha}^{-1}$ mampu menekan pertumbuhan gulma total, gulma golongan rumput dan gulma dominan (Centocheca lappacea, Cyrtococcum acrescens, Ottochloa nodosa) pada tanaman karet dari 4 MSA sampai dengan 12 MSA, sedangkan gulma golongan daun lebar dan gulma dominan Sellaginella willdenowii hanya pada 4 MSA pada perkebunan karet menghasilkan, dan terdapat perubahan komposisi gulma yang tumbuh setelah aplikasi herbisida glifosat, gulma golongan daun lebar menjadi dominan.
\end{abstract}

Kata kunci : glifosat, gulma, herbisida, karet.

\section{PENDAHULUAN}

Pengembangan perkebunan karet memberikan peranan penting bagi perekonomian nasional, yaitu sebagai sumber devisa, sumber bahan baku industri, sumber pendapatan dan kesejahteraan masyarakat serta sebagai pengembangan pusat-pusat pertumbuhan perekonomian di daerah dan sekaligus berperan dalam pelestarian fungsi lingkungan hidup (Deptan, 2012).

Salah satu aspek budidaya tanaman perkebunan yang sangat penting adalah pengendalian terhadap gulma. Gulma dapat menurunkan hasil dengan cara berkompetisi dengan tanaman pokok, disamping itu gulma dapat sebagai inang alternatif hama dan penyakit tanaman. Apabila gulma yang ada sebagai inang pengganti hama penyakit, maka penurunan hasilnya sangat merugikan perkebunan, oleh sebab itu perlu dikendalikan. Pengendalian gulma dapat dilakukan dengan berbagai cara, menurut Sukman dan Yakup (1995), ada beberapa metode pengendalian gulma yaitu pengendalian dengan upaya preventif, mekanis/fisik, kultur teknik, hayati dan kimiawi.
Glifosat merupakan herbisida yang bersifat sistemik dan tidak selektif pascatumbuh. Glifosat dapat berpengaruh pada pigmen hingga terjadi klorotik, pertumbuhan terhenti dan pertumbuhan dapat mati (Moenandir, 2010). Glifosat mampu mengendalikan gulma hingga 42 HSA dikarenakan herbisida terserap dengan baik hingga mencapai akar sedangkan herbisida lainnya telah mengalami penurunan kemampuan pengendalian gulma (Adnan,2012)

Pengendalian gulma secara kimia terhadap gulma umum pada budidaya keret menghasilkan menggunakan isopropilamina (IPA) glifosat diharapkan mampu menekan pertumbuhan gulma. Glifosat adalah herbisida yang mempunyai spektrus pengendalian luas bersifat nonselektif. Menurut Sriyani (2008) glifosat sangat efektif mengendalikan gulma rumput dan daun lebar yang mempunyai perakaran dalam dan diaplikasikan sebagai herbisida pascatumbuh. Tujuan dari penelitian ini adalah untuk mengetahui efektifitas herbisida glifosat terhadap pengendalian gulma pada perkebunan karet menghasilkan dan untuk mengetahui perubahan komposisi gulma setelah aplikasi herbisida glifosat. 


\section{BAHAN DAN METODE}

Penelitian ini dilakukan di lahan perkebunan PTPN VII Unit Usaha Way Galih dan Laboratorium Gulma Fakultas Pertanian Universitas Lampung dari bulan Januari 2012 sampai April 2013. Bahan yang digunakan adalah tanaman karet berumur 20 tahun dan herbisida yang berbahan aktif isopropil amina glifosat.

Pengolahan data dikerjakan dengan metode analisis ragam. Dilanjutkan dengan pemisahan nilai tengah yang diuji dengan Beda Nyata Terkecil pada taraf $5 \%$ dan perbedaan nilai rata-rata perlakuan pada taraf nyata $95 \%$. Homogenitas ragam antar perlakuaan diuji dengan uji Barlett dan aditivitas diuji dengan uji Tukey.

Perlakuan disusun dalam rancangan kelompok teracak sempurna yang terdiri atas 6 perlakuan dengan 4 ulangan. Enam perlakuan dalam penelitian ini yaitu :

1. Perlakuan $1:$ herbisida glifosat dengan dosis formulasi $1,51 \mathrm{ha}^{-1}$ dan dosis bahan aktif $720 \mathrm{~g} \mathrm{ha}^{-1}$.

2. Perlakuan 2 : herbisida glifosat dengan dosis formulasi 2,0 $1 \mathrm{ha}^{-1}$ dan dosis bahan aktif $960 \mathrm{~g} \mathrm{ha}^{-1}$.

3. Perlakuan 3 : herbisida glifosat dengan dosis formulasi 2,5 $1 \mathrm{ha}^{-1}$ dan dosis bahan aktif $1200 \mathrm{~g} \mathrm{ha}^{-1}$.

4. Pelakuan 4 : herbisida glifosat dengan dosis formulasi 3,0 1 ha $^{-1}$ dan dosis bahan aktif $1440 \mathrm{~g} \mathrm{ha}^{-1}$.

5. Perlakuan 5 : penyiangan mekanis.

6. Perlakuan 6 : kontrol.

Setiap perlakuan terdiri dari 5 tanaman yang berjarak $3 \mathrm{~m} \times 7 \mathrm{~m}$. Volume seprot yang digunakan pada saat aplikasi 2,301 per $45 \mathrm{~m}^{2}$. Variabel yang diamati pada percobaan ini meliputi bobot kering gulma total, bobot kering gulma golongan daun lebar, bobot kering gulma golongan rumput, bobot kering gulma dominan dan koefisien kominitas.

\section{HASIL DAN PEMBAHASAN}

Produksi tanaman pertanian, baik yang diusahakan dalam bentuk pertanian rakyat ataupun perkebunan besar ditentukan oleh beberapa faktor antara lain permasalahan terhadap gulma. Kerugian akibat gulma terhadap tanaman budidaya bervariasi, tergantung dari jenis tanamannya, iklim, jenis gulmanya, dan tentu saja praktek pertanian di samping faktor lain. Persaingan antara gulma dengan tanaman yang kita usahakan dalam mengambil unsur-unsur hara dan air dari dalam tanah dan penerimaan cahaya matahari untuk proses fotosintesis, menimbulkan kerugian-kerugian dalam produksi baik kualitas maupun kuantitas. Data yang diperoleh dalam percobaan ini meliputi bobot kering golongan daun lebar, bobot kering gulma golongan rumput, bobot kering gulma dominan, koefisien komunitas dan bobot kering gulma gulma total.

Berdasarkan pengamatan bobot kering gulma golongan rumput pada 4, 8 dan 12 MSA dapat dilihat bahwa herbisida glifosat mampu menekan pertumbuhan gulma golongan rumput. Menurut penelitian Girsang (2005), herbisida glifosat merupakan herbisida yang efektif untuk mengendalikan gulma golongan rumput hingga 2 bulan setelah aplikasi. Sehingga dapat dikatakan bahwa pemberian glifosat dengan semua perlakuan dapat mengendalikan gulma golongan rumput dari 4 MSA sampai 12 MSA. Menurut Tomlim (2009), glifosat merupakan penghambat 5-enolpyruvylshikimate-3-phosphonate synthase (EPSPS), yaitu enzim yang memengaruhi biosintesis asam aromatik. Dengan adanya glifosat, sintesis asam amino yang penting untuk pembentukan protein akan terhambat. Cara kerjanya non selektif herbisida sistemik, diserap oleh daun lalu cepat ditranslokasikan ke seluruh jaringan tumbuhan.

Tabel 1 menunjukkan semua dosis yang diuji pada 4 MSA mampu menekan pertumbuhan gulma golongan daun lebar, daya kendali glifosat 720-1440 $\mathrm{g} \mathrm{ha}^{-1}$ sebanding dengan perlakuaan mekanis. Sedangkan antar perlakuan herbisida tidak menunjukkan adanya perbedaan pertumbuhan gulma. Hal ini menandakan bahwa glifosat efektif dalam mengendalikan berbagai gulma termasuk gulma berdaun lebar (Riadi, 2011). Namun pada 8 MSA hanya perlakuan glifosat 960-1440 $\mathrm{g} \mathrm{ha}^{-1}$ yang mampu menekan pertumbuhan gulma daun lebar dan pada 12 MSA hanya perlakuan glifosat dengan dosis $960 \mathrm{~g} \mathrm{ha}^{-1}$ yang mampu menekan pertumbuhan gulma daun lebar. Sedangkan antar perlakuan herbisida menunjukkan adanya perbedaan pertumbuhan gulma. Translokasi herbisida glifosat dalam tumbuhan berlangsung secara simplastik yaitu melalui jaringan hidup dengan pembuluh utama floem bersamaan dengan translokasi hasil fotosintesis (Sriyani, 2013).

Gulma dominan yang terdapat pada petak percobaan antara lain Centocheca lappacea, Ottochloa nodosa, dan Sellaginella willdenowii. Gulma dominan tersebut diperoleh berdasarkan gulma dominan yang terdapat pada petak kontrol (Tabel 2).

Dari hasil pengamatan semua dosis glifosat yang diuji tidak efektif mengendalikan pertumbuhan gulma Centocheca lappacea. hal ini dapat dilihat dari bobot kering gulma Centocheca lappacea yang dibandingkan dengan kontrol pada 4 MSA(Tabel 3). Aplikasi glifosat pada 4 MSA belum dapat menekan bobot kering gulma Centocheca lappacea karena herbisida yang diserap oleh gulma belum bekerja dengan baik sehingga herbisida 
Tabel 1. Pengaruh aplikasi herbisida glifosat terhadap bobot kering gulma golongan daun lebar $\left(\mathrm{g} / 0,5 \mathrm{~m}^{2}\right)$

\begin{tabular}{lcccccccc}
\hline \multirow{2}{*}{ Perlakuan } & \multicolumn{3}{c}{4 MSA } & \multicolumn{3}{c}{8 MS A } & \multicolumn{3}{c}{12 MSA } \\
\cline { 2 - 8 } & \multicolumn{2}{c}{ Asli } & Asli & Trans $(\sqrt{ } \sqrt{ }(x+0,5))$ & Asli & \multicolumn{2}{c}{$\operatorname{Trans}(\sqrt{ } \sqrt{ }(x+0,5))$} \\
\hline Glifosat $720 \mathrm{~g} / \mathrm{ha}$ & 6,34 & $\mathrm{~b}$ & 16,72 & 1,36 & $\mathrm{ab}$ & 5,60 & 1,06 & $\mathrm{abc}$ \\
Glifosat $960 \mathrm{~g} / \mathrm{ha}$ & 6,76 & $\mathrm{~b}$ & 2,51 & 1,11 & $\mathrm{bc}$ & 0,00 & 0,92 & $\mathrm{c}$ \\
Glifosat $1200 \mathrm{~g} / \mathrm{ha}$ & 3,25 & $\mathrm{~b}$ & 10,71 & 1,19 & $\mathrm{abc}$ & 16,25 & 1,36 & $\mathrm{a}$ \\
Glifosat $1440 \mathrm{~g} / \mathrm{ha}$ & 6,11 & $\mathrm{~b}$ & 2,83 & 1,08 & $\mathrm{bc}$ & 3,52 & 1,05 & $\mathrm{bc}$ \\
Mekanis & 0,02 & $\mathrm{~b}$ & 0,00 & 0,92 & $\mathrm{c}$ & 0,00 & 0,92 & $\mathrm{c}$ \\
Kontrol & 37,48 & $\mathrm{a}$ & 41,55 & 1,47 & $\mathrm{a}$ & 16,90 & 1,29 & $\mathrm{ab}$ \\
\hline \multicolumn{1}{c}{ BNT 0,05} & 22,67 & 0,35 & & 0,31 & \\
\hline
\end{tabular}

Keterangan : Nilai tengah pada setiap kolom yang diikuti oleh huruf yang sama tidak berbeda nyata menurut uji BNT pada taraf $5 \%$.

Tabel 2. Pengaruh aplikasi herbisida glifosat terhadap bobot kering gulma Centocheca lappacea $\left(\mathrm{g} / 0,5 \mathrm{~m}^{2}\right)$

\begin{tabular}{lccccccccc}
\hline \multirow{2}{*}{ Perlakuan } & \multicolumn{3}{c}{4 MSA } & \multicolumn{3}{c}{8 MSA } & \multicolumn{2}{c}{12 MSA } \\
\cline { 2 - 10 } & Asli & $\begin{array}{c}\text { Trans } \\
(\sqrt{ } \sqrt{ }(\mathrm{x}+0,5))\end{array}$ & Asli & $\begin{array}{c}\text { Trans } \\
(\sqrt{ } \sqrt{ }(\mathrm{x}+0,5))\end{array}$ & Asli & $\begin{array}{c}\text { Trans } \\
(\sqrt{ } \sqrt{ }(\mathrm{x}+0,5))\end{array}$ \\
\hline Glifosat $720 \mathrm{~g} / \mathrm{ha}$ & 1,93 & 1,01 & $\mathrm{a}$ & 0,25 & 0,95 & $\mathrm{ab}$ & 0,00 & 0,92 & $\mathrm{~b}$ \\
Glifosat $960 \mathrm{~g} / \mathrm{ha}$ & 5,06 & 1,05 & $\mathrm{a}$ & 0,19 & 0,94 & $\mathrm{ab}$ & 0,00 & 0,92 & $\mathrm{~b}$ \\
Glifosat $1200 \mathrm{~g} / \mathrm{ha}$ & 0,00 & 0,92 & $\mathrm{a}$ & 0,00 & 0,92 & $\mathrm{~b}$ & 0,00 & 0,92 & $\mathrm{~b}$ \\
Glifosat $1440 \mathrm{~g} / \mathrm{ha}$ & 0,00 & 0,92 & $\mathrm{a}$ & 0,00 & 0,92 & $\mathrm{~b}$ & 0,00 & 0,92 & $\mathrm{~b}$ \\
Mekanis & 0,11 & 0,93 & $\mathrm{a}$ & 0,00 & 0,92 & $\mathrm{~b}$ & 0,00 & 0,92 & $\mathrm{~b}$ \\
Kontrol & 6,83 & 1,09 & $\mathrm{a}$ & 1,90 & 1,04 & $\mathrm{a}$ & 13,62 & 1,24 & $\mathrm{a}$ \\
\hline \multicolumn{1}{c}{ BNT 0,05 } & \multicolumn{3}{c}{0,27} & & 0,18 & & & 0,19
\end{tabular}

Keterangan : Nilai tengah pada setiap kolom yang diikuti oleh huruf yang sama tidak berbeda nyata menurut uji BNT pada taraf $5 \%$.

tersebut belum ditranslokasikan secara simplastik melalui floem maupun secara apoplastik melalui xylem keseluruh bagian gulma. Hal ini menyebabkan herbisida belum mampu menekan pertumbuhan gulma Centocheca lappacea.

Pada 8 MSA yang menunjukan data glifosat dengan dosis 1200-1440 $\mathrm{g} \mathrm{ha}^{-1}$ mampu mengendalikan pertumbuhan gulma Centocheca lappacea, kecuali dosis rendah. Namun pada 12 MSA hasil pengamatan menunjukkan bahwa semua perlakuan herbisida mampu mengendalikan gulma Centocheca lappacea di lihat dari data yang sebanding dengan perlakuan mekanis. Sedangkan antar perlakuan herbisida tidak menunjukkan adanya perbedaan pertumbuhan gulma.

Data bobot kering gulma Cyrtococcum acrescens disajikan dalam tabel 6. Data tersebut menunjukkan bahwa glifosat (720-1440 $\mathrm{g} \mathrm{ha}^{-1}$ ) mampu menekan pertumbuhan gulma Cyrtococcum acrescens sampai 12 MSA(Tabel 4). Dapat dilihat dari data yang sebanding dengan perlakuan mekanis. Sedangkan antar perlakuan herbisida tidak menunjukkan adanya perbedaan pertumbuhan gulma kecuali dosis rendah pada 8 MSA. Artinya aplikasi glifosat pada dosis rendah sekalipun dapat m engendalikan gulm a Cyrtococcum acrescens pada perkebunan karet.

Cyrtoccocum acrescens termasuk kedalam kelas monokotil, mempunyai pertumbuhan meristem lateral dan memiliki banyak titik tumbuh, sehingga dibutuhkan waktu yang lebih lama untuk mematikannya (Nasution, 1989). Ditinjau dari morfologi, gulma Cyrtoccocum acrescens mempunyai daun yang ditumbuhi bulu-bulu halus sehingga herbisida mengalami hambatan untuk untuk masuk kedalam jaringan gulma.

Berdasarkan pengamatan bobot kering gulma Ottochloa nodosa pada 4, 8 dan 12 MSA dapat dilihat bahwa herbisida glifosat mampu menekan pertumbuhan 
Tabel 3. Pengaruh aplikasi herbisida glifosat terhadap bobot kering gulma Cyrtococcum acrescens $\left(\mathrm{g} / 0,5 \mathrm{~m}^{2}\right)$

\begin{tabular}{|c|c|c|c|c|c|c|c|c|c|}
\hline \multirow{3}{*}{$\begin{array}{l}\text { Perlakuan } \\
\text { sat } 720 \mathrm{~g} / \mathrm{ha}\end{array}$} & \multicolumn{3}{|c|}{$4 \mathrm{MSA}$} & \multicolumn{3}{|c|}{8 MSA } & \multicolumn{3}{|c|}{$12 \mathrm{MSA}$} \\
\hline & \multirow{2}{*}{$\begin{array}{l}\text { Asli } \\
0,00\end{array}$} & \multicolumn{2}{|c|}{$\begin{array}{c}\text { Trans } \\
(\sqrt{ } \sqrt{ } \sqrt{ }(x+0,5))\end{array}$} & Asli & \multicolumn{2}{|c|}{$\begin{array}{c}\text { Trans } \\
(\sqrt{ } \sqrt{ } \sqrt{ }(x+0,5))\end{array}$} & Asli & \multicolumn{2}{|c|}{$\begin{array}{r}\text { Trans } \\
(\sqrt{ } \sqrt{ } \sqrt{ }(x+0,5))\end{array}$} \\
\hline & & 0,92 & $\mathrm{~b}$ & 0,96 & 0,99 & $a b$ & 0,00 & 0,92 & $\mathrm{~b}$ \\
\hline Glifosat $960 \mathrm{~g} / \mathrm{ha}$ & 0,48 & 0,97 & $\mathrm{~b}$ & 0,00 & 0,92 & $\mathrm{~b}$ & 0,00 & 0,92 & $\mathrm{~b}$ \\
\hline Glifosat $1200 \mathrm{~g} / \mathrm{ha}$ & 0,00 & 0,92 & $\mathrm{~b}$ & 0,00 & 0,92 & $\mathrm{~b}$ & 0,00 & 0,92 & $\mathrm{~b}$ \\
\hline Glifosat $1440 \mathrm{~g} / \mathrm{ha}$ & 0,00 & 0,92 & $\mathrm{~b}$ & 0,00 & 0,92 & $\mathrm{~b}$ & 0,00 & 0,92 & $\mathrm{~b}$ \\
\hline Mekanis & 0,00 & 0,92 & $\mathrm{~b}$ & 0,00 & 0,92 & $\mathrm{~b}$ & 0,00 & 0,92 & $\mathrm{~b}$ \\
\hline Kontrol & 20,76 & 1,33 & $\mathrm{a}$ & 9,55 & 1,18 & $\mathrm{a}$ & 18,16 & 1,30 & $\mathrm{a}$ \\
\hline BNT 0,05 & & 0,19 & & & 0,20 & & & 0,18 & \\
\hline
\end{tabular}

Keterangan : Nilai tengah pada setiap kolom yang diikuti oleh huruf yang sama tidak berbeda nyata menurut uji BNT pada taraf $5 \%$.

Tabel 4. Pengaruh aplikasi herbisida glifosat terhadap bobot kering gulma Ottochloa nodosa $\left(\mathrm{g} / 0,5 \mathrm{~m}^{2}\right)$

\begin{tabular}{|c|c|c|c|c|c|c|c|c|c|}
\hline \multirow{3}{*}{$\begin{array}{l}\text { Perlakuan } \\
\text { at } 720 \mathrm{~g} / \mathrm{ha}\end{array}$} & \multicolumn{3}{|c|}{$4 \mathrm{MSA}$} & \multicolumn{3}{|c|}{8 MSA } & \multicolumn{3}{|c|}{$12 \mathrm{MSA}$} \\
\hline & \multirow{2}{*}{$\begin{array}{l}\text { As li } \\
0,33\end{array}$} & \multicolumn{2}{|c|}{$\begin{array}{c}\text { Trans } \\
(\sqrt{ } \sqrt{ } \sqrt{ }(x+0,5)) \\
\end{array}$} & Asli & \multicolumn{2}{|c|}{$\begin{array}{c}\text { Trans } \\
(\sqrt{ } \sqrt{ } \sqrt{ }(x+0,5)) \\
\end{array}$} & \multirow{2}{*}{$\begin{array}{l}\text { Asli } \\
0,00\end{array}$} & \multicolumn{2}{|c|}{$\begin{array}{r}\text { Trans } \\
(\sqrt{ } \sqrt{ }(x+0,5))\end{array}$} \\
\hline & & 0,96 & $\mathrm{~b}$ & 0,00 & 0,92 & $\mathrm{~b}$ & & 0,92 & $\mathrm{~b}$ \\
\hline Glifosat $960 \mathrm{~g} / \mathrm{ha}$ & 0,00 & 0,91 & $\mathrm{~b}$ & 0,89 & 0,98 & $\mathrm{~b}$ & 0,00 & 0,98 & $\mathrm{~b}$ \\
\hline Glifosat $1200 \mathrm{~g} / \mathrm{ha}$ & 0,16 & 0,94 & $\mathrm{~b}$ & 0,00 & 0,92 & $\mathrm{~b}$ & 0,00 & 0,92 & $\mathrm{~b}$ \\
\hline Glifosat $1440 \mathrm{~g} / \mathrm{ha}$ & 1,05 & 0,99 & $a b$ & 0,00 & 0,92 & $\mathrm{~b}$ & 0,75 & 0,92 & $\mathrm{~b}$ \\
\hline Mekanis & 0,00 & 0,91 & $\mathrm{~b}$ & 0,00 & 0,92 & $\mathrm{~b}$ & 0,00 & 0,92 & $\mathrm{~b}$ \\
\hline Kontrol & 9,30 & 1,17 & $\mathrm{a}$ & 10,55 & 1,26 & $\mathrm{a}$ & 7,17 & 1,26 & $\mathrm{a}$ \\
\hline BNT 0,05 & & 0,21 & & & 0,17 & & & 0,17 & \\
\hline
\end{tabular}

Keterangan : Nilai tengah pada setiap kolom yang diikuti oleh huruf yang sama tidak berbeda nyata menurut uji BNT pada taraf $5 \%$.

gulma Ottochloa nodosa dapat dilihat dari data yang sebanding dengan perlakuan mekanis. Artinya aplikasi glifosat pada dosis rendah sekalipun dapat dijadikan salah satu cara pengendalian gulma Ottochloa nodosa untuk menggantikan penyiangan mekanis pada perkebunan karet. Sedangkan antar perlakuan herbisida tidak menunjukkan adanya perbedaan pertumbuhan gulma kecuali dosis $1440 \mathrm{~g} \mathrm{ha}^{-1}$ pada 4 MSA. Pada petak perlakuan dosis herbisida glifosat tertinggi belum ditemukan adanya gulma yang muncul (Nurjanah 2003).

Data bobot kering gulma Sellaginella willdenowii disajikan dalam Tabel 5 Data tersebut Sellaginella willdenowii menunjukkan bahwa glifosat (960-1440 $\mathrm{g} \mathrm{ha}^{-1}$ ) mampu menekan pertumbuhan gulma Sellaginella willdenowii pada 4 MSA. Dapat dilihat dari data yang sebanding dengan perlakuan mekanis.
Sedangkan antar perlakuan herbisida tidak menunjukkan adanya perbedaan pertumbuhan gulma. Namun demikian, pada 8 MSA perlakuan glifosat $960 \mathrm{~g} \mathrm{ha}^{-1}$ dan $1440 \mathrm{~g} \mathrm{ha}^{-1}$ yang mampu menekan pertumbuhan gulma Sellaginella willdenowii sedangkan dengan dosis yang rendah tidak menunjukkan respon yang baik. Sedangkan antar perlakuan herbisida menunjukkan adanya perbedaan pertumbuhan gulma.

Pada 12 MSA hanya dosis $960 \mathrm{~g} \mathrm{ha}^{-1}$ yang mampu mengendalikan gulma Sellaginella willdenowii sedangkan dosis yang lainnya tidak menunjukkan respon yang baik. Antar perlakuan herbisida menunjukkan adanya perbedaan pertumbuhan gulma.

Data bobot kering gulma total disajikan dalam Tabel 6. Data tersebut menunjukkan bahwa glifosat (720 $-1440 \mathrm{~g} \mathrm{ha}^{-1}$ ) efektif mengendalikan gulma total sampai 
Tabel 5. Pengaruh aplikasi herbisida glifosat terhadap bobot kering gulma Sellaginella willdenowii $\left(\mathrm{g} / 0,5 \mathrm{~m}^{2}\right)$

\begin{tabular}{lcccccccc}
\hline \multirow{2}{*}{ Perlakuan } & \multicolumn{3}{c}{4 MSA } & \multicolumn{3}{c}{8 MS A } & \multicolumn{3}{c}{12 MSA } \\
\cline { 2 - 9 } & \multicolumn{2}{c}{ Asli } & Asli & Trans $(\sqrt{ } \sqrt{ }(\mathrm{x}+0,5))$ & Asli & Trans $(\sqrt{ } \sqrt{ }(\mathrm{x}+0,5))$ \\
\hline Glifosat $720 \mathrm{~g} / \mathrm{ha}$ & 5,30 & $\mathrm{~b}$ & 14,84 & 1,30 & $\mathrm{ab}$ & 5,60 & 1,06 & $\mathrm{ab}$ \\
Glifosat $960 \mathrm{~g} / \mathrm{ha}$ & 6,00 & $\mathrm{~b}$ & 1,77 & 1,05 & $\mathrm{bc}$ & 0,00 & 0,92 & $\mathrm{~b}$ \\
Glifosat $1200 \mathrm{~g} / \mathrm{ha}$ & 1,12 & $\mathrm{~b}$ & 10,71 & 1,19 & $\mathrm{abc}$ & 15,93 & 1,33 & $\mathrm{a}$ \\
Glifosat $1440 \mathrm{~g} / \mathrm{ha}$ & 0,85 & $\mathrm{~b}$ & 0,46 & 0,96 & $\mathrm{bc}$ & 3,45 & 1,04 & $\mathrm{ab}$ \\
Mekanis & 0,02 & $\mathrm{~b}$ & 0,00 & 0,92 & $\mathrm{c}$ & 0,00 & 0,92 & $\mathrm{~b}$ \\
Kontrol & 30,49 & $\mathrm{a}$ & 40,50 & 1,46 & $\mathrm{a}$ & 16,20 & 1,28 & $\mathrm{a}$ \\
\hline \multicolumn{1}{c}{ BNT 0,05} & 18,29 & 0,35 & & 0,33 & \\
\hline
\end{tabular}

Keterangan : Nilai tengah pada setiap kolom yang diikuti oleh huruf yang sama tidak berbeda nyata menurut uji BNT pada taraf $5 \%$.

Tabel 6. Pengaruh aplikasi herbisida glifosat terhadap bobot kering gulma total $\left(\mathrm{g} / 0,5 \mathrm{~m}^{2}\right)$.

\begin{tabular}{lclccccc}
\hline \multirow{2}{*}{ Perlakuan } & \multicolumn{2}{c}{4 MSA } & \multicolumn{3}{c}{8 MSA } & \multicolumn{3}{c}{12 MSA } \\
\cline { 2 - 8 } & \multicolumn{2}{c}{ Asli } & Asli & Trans $(\sqrt{ } \sqrt{ }(\mathrm{x}+0,5))$ & Asli \\
\hline Glifosat $720 \mathrm{~g} / \mathrm{ha}$ & 8,80 & $\mathrm{bc}$ & 17,93 & 1,40 & $\mathrm{ab}$ & 7,22 & $\mathrm{~b}$ \\
Glifosat $960 \mathrm{~g} / \mathrm{ha}$ & 12,30 & $\mathrm{~b}$ & 3,59 & 1,15 & $\mathrm{bcd}$ & 0,73 & $\mathrm{~b}$ \\
Glifosat $1200 \mathrm{~g} / \mathrm{ha}$ & 4,38 & $\mathrm{bc}$ & 10,71 & 1,19 & $\mathrm{bc}$ & 16,27 & $\mathrm{~b}$ \\
Glifosat $1440 \mathrm{~g} / \mathrm{ha}$ & 7,16 & $\mathrm{bc}$ & 2,83 & 1,08 & $\mathrm{~cd}$ & 4,27 & $\mathrm{~b}$ \\
Mekanis & 0,12 & $\mathrm{c}$ & 0,00 & 0,92 & $\mathrm{~d}$ & 0,08 & $\mathrm{~b}$ \\
Kontrol & 74,38 & $\mathrm{a}$ & 63,54 & 1,66 & $\mathrm{a}$ & 57,04 & $\mathrm{a}$ \\
\hline BNT 0,05 & 11,31 & & 0,27 & & 16,29 &
\end{tabular}

Keterangan : Nilai tengah pada setiap kolom yang diikuti oleh huruf yang sama tidak berbeda nyata menurut uji BNT pada taraf $5 \%$.

12 MSA, daya kendali glifosat 720-1440 $\mathrm{g} \mathrm{ha}^{-1}$ sebanding dengan perlakuaan mekanis. Sedangkan antar perlakuan herbisida menunjukkan adanya perbedaan pertumbuhan gulma.

Hal ini berarti pada 4, 8 dan 12 MSA, glifosat telah diabsorsi oleh daun, lalu ditranslokasikan keseluruh bagian gulma sehingga menghambat pertumbuhan gulma. Daya kendali glifosat $960 \mathrm{~g} \mathrm{ha}^{-1} \mathrm{~s} / \mathrm{d} 1440 \mathrm{~g} \mathrm{ha}^{-1}$ sebanding dengan penyiangan manual. Hal ini karena glifosat yang telah ditranslokasikan ke seluruh bagian tubuh gulma terutama pada bagian akar yang dapat menyebabkan kematian gulma secara lebih efektif (Johal dan Huber 2009).

Tujuan pengendalian gulma pada perkebunan karet menghasilkan yaitu mengurangi populasi gulma agar tidak berkompetisi dengan tanaman karet dalam memperebutkan unsur hara, cahaya matahari, air, karbon dioksida, dan ruang tumbuh sehingga tidak menekan pertumbuhan tanaman. Pengaplikasian herbisida glifosat pada perkebunan karet menghasilkan merupakan salah satu teknik pengendalian gulma secara kimiawi. Variabel pengamatan dilakukan pada tiap petak percobaan yang meliputi bobot kering gulma total dan tingkat dominansi gulma. Berdasarkan hasil penelitian ini, dosis herbisida glifosat yang direkomendasikan untuk mengendalikan gulma pada perkebunan karet menghasilkan yaitu glifosat dosis $720 \mathrm{~g} \mathrm{ha}^{-1}$ karena mampu menekan bobot gulma total hingga 12 MSA untuk memperhitungkan aspek ekonomi. Biaya yang diperlukan dalam penyiangan mekanis sekitar Rp. 300.000 per ha sedangkan biaya menggunakan herbisida hanya sekitar Rp.75.000 per ha.

\section{KESIMPULAN}

Herbisida glifosat pada dosis $720 \mathrm{~g} \mathrm{ha}^{-1}-1440$ $\mathrm{g} \mathrm{ha}^{-1}$ mampu menekan pertumbuhan gulma total, gulma golongan rumput dan gulma dominan (Centocheca 
lappacea, Cyrtococcum acrescens, Ottochloa nodosa) pada tanaman karet dari 4 MSA sampai dengan 12 MSA, sedangkan gulma golongan daun lebar dan gulma dominan Sellaginella willdenowii hanya pada 4 MSA pada perkebunan karet menghasilkan. Terdapat perubahan komposisi gulma yang tumbuh setelah aplikasi herbisida glifosat, gulma golongan daun lebar menjadi dominan.

\section{DAFTAR PUSTAKA}

Adnan. 2012. Aplikasi Beberapa Dosis Herbisida Glifosat dan Paraquat pada Sistem Tanpa Olah Tanah (TOT) serta Pengaruhnya terhadap Sifat Kimia Tanah, Karakteristik Gulma dan Hasil Kedelai. J. Agrista. 16 (3) : 135-145

Deptan. 2012. Karet. www. Deptan co.id. Diakses pada tanggal : 17 Desember 2012.

Girsang, W. 2005. Pengaruh tingkat dosis herbisida isopropilamina glifosat dan selang waktu terjadinya pencucian setelah aplikasi terhadap efektifitas pengendalian gulma pada perkebunan karet (Hevea brassiliensis) TBM. Jurnal Penelitian Bidang Ilmu Pertanian. 3(2): 31-36.

Johal, S.G. and D.M. Huber. 2009. Glyphosate effects on diseases of plants. Europ. J. Agronomy. 31 (1) : 144-152.
Nasution, U. 1989. Gulma dan Pengendaliannya di Perkebunana Karet Sumatera Utara dan Aceh. Puslitbang Perkebunan Tanjung Morawa (P4TM).

Nurjanah, U. 2003. Pengaruh Dosis Herbisida Glifosat dan 2.4-D terhadap Pergeseran Gulma dan Tanaman Kedelai Tanpa Olah Tanah. J. Ilmuilmu Pertanian Indonesia. 5 (1) : 27-33

Moenandir, J. 2010. Ilmu Gulma. Universitas Brawijaya Press. Malang. 157 hal.

Riadi, M. 2011. Mata Kuliah: Herbisida dan aplikasinya. Bahan Ajar. Universitas Hasanuddin. $138 \mathrm{hlm}$.

Sriyani, N. 2008. Bahan Kuliah Ilmu dan Teknik Pengendalian Gulma. (Tidak Dipublikasikan). Universitas Lampung. Bandar Lampung.

Sriyani, N. D. Mawardi, dan M. V. Rini. 2003. Evaluasi Penggunaan Herbisida Glifosat Formulasi Baru (K-Glifosat) untuk Mengendalikan Gulma pada Perkebunan Besar Karet dan Kelapa Sawit. Jurnal Agrotropika. 8(1) : 31-36.

Sukman, Y. dan Yakup. 1995. Gulma dan Teknik Pengendaliannya. PT. Raja Grafindo Persada. Jakarta. 152 hal.

Tjitrosoedirdjo, S., I.H. Utomo, dan J. Wiroatmodjo. 1984. Pengelolaan Gulma di Perkebunan. PT. Gramedia. Jakarta. 209 hal.

Tomlin, C. D. S. 2009. A World Compedium The Pesticide Manual. Fifteenth ed. British Crop Protection Council. Inggris. 1606 hal. 